\title{
Mentorship needs of early career teachers working in rural regions
}

\author{
Seçil Eda Kartal \\ Bartın University, Faculty of Education, Bartın, Turkey, seciledakartal@gmail.com \\ Tuncay Yavuz Özdemir \\ Firat University, Faculty of Education, Elazig, Turkey, tyavuz23@gmail.com \\ Ramazan Yirci \\ Kahramanmaraş Sütçüimam University, Faculty of Education, Kahramanmaraş, ryirci@gmail.com
}

\begin{abstract}
The purpose of this study is to identify the problems that teachers working in rural regions encounter concerning the Turkish educational system during the years they lack knowledge and experience and to determine their needs for mentorship services. The data was collected through an interview form and 11 teachers who works in rural regions participated into the research voluntarily. The study group was defined using purposeful sampling method. The data were analyzed through the content analysis processes. According to the findings of the study; teachers working in rural regions encounter serious problems in time management during the early years of their profession and that the effectiveness of presenting teaching contents decrease due to lack of family participation, low level of student academic achievement, poor physical conditions of the school and insufficient amount of teaching materials. It was also observed that they had problems in administrative issues and official correspondence. Arranging effective in-service training activities and offering mentorship services for inexperienced teachers in rural regions may help to resolve these problems.
\end{abstract}

Keywords Teacher training, mentoring, teacher qualifications, professional development, mentoring needs

\section{Kırsalda çalışan öğretmenlerin mesleğin ilk yıllarında mentorluk ihtiyaçları}

ÖZ Bu çalışma ile Türk eğitim sisteminde kırsalda görevli öğretmenlerin bilgi ve deneyim eksikliği yaşadıkları dönemlerde yaşadıkları sorunların belirlenerek, mentorluk hizmetine olan gereksinimlerinin tespit edilmesi amaçlanmıştır. Araştırmada veriler görüşme formu aracılığıyla toplanmış ve araştırmaya kırsal bölgelerde çalışan 11 öğretmen gönüllük esasına göre katılmışlardır. Çalışma grubunun belirlenmesinde amaçlı örnekleme yöntemi kullanılmıştır. Verilerin analizinde nitel araştırma yöntemlerinden içerik analizi yöntemi kullanılmıştır. Araştırma sonucunda ulaşılan bulgular; kırsalda görevli öğretmenlerin görevlerinin ilk yıllarında zaman yönetiminde ciddi sıkıntılar yaşadığı, aile katılımının yetersiz oluşu ile öğrencilerin akademik başarı düzeylerinin düşük olması ve okulun fizik şartlarının yetersizliği ile öğretim materyallerinin eksik oluşu birleşince öğretim içeriğinin sunumunda verimliliğin azaldığ 1 belirlenmiştir. İdari işlerin yürütülmesinde, resmi yazışmalarda sorun yaşandığı tespit edilmiştir. Bütün bu olumsuzlukların giderilmesi açısından etkin hizmetiçi eğitim etkinliklerin düzenlenmesi ve kırsalda görevli öğretmenlerin görevlerinin ilk yıllarında deneyimi az öğretmenlere yol gösterici ya da bir mentorun rehberlik etmesi mentorluk hizmetinin sunulması önemli görülmektedir.

Anahtar

Kelimeler

Öğretmen yetiştirme, mentorluk, mentorluk ihtiyacl,mesleki gelişim, öğretmen yeterlikleri 


\section{INTRODUCTION}

Today, the concept mentor, which dates back to Odyssey (Harris, 1993; Strong, 2009) of the Greek mythology, is defined as the expert person who supports the development of novice individuals (Roberts, 2000; Cakir \& Kocabas, 2016). Mentee (Klasen \& Cluutterbuck, 2002) is the person with less experience and who is delivered to the mentor, the process in which the knowledge and experience sharing takes place between the mentor and mentee is defined as the mentoring process (Ozdemir, 2012). Mentoring refers to the relationship that organizes people with equal or imbalanced status or to the long term relationship between the master (experienced) and apprentice (less experienced) (Godshalk and Sosik, 2003; Kocabas \& Yirci, 2011; McManus \& Russell, 1997; Singh, Bains, \& Vinnicombe, 2002; Young \& Perrewe, 2000; Bozionelos, 2004).

The mentoring process can take place through three different ways (Ozdemir, 2012). Formal mentorship refers to the mentoring process carried out by creating an organizational learning environment so as to support professional development (Sosik \& Lee, 2005). Informal mentorship is the mentoring process which is less planned than formal mentorship (Klasen \& Clutterbuck, 2005) and the mentor-mentee matching is mutual preferential (Underhill, 2006). Mentorship carried out through the internet is defined as electronic mentoring (Brescia, 2002).

Fulfilment of mentor and mentee responsibilities (Yirci \& Kocabas, 2010) and the harmony between the mentor and mentee (Clutterbuck \& Ragins, 2002) are crucial for the effectiveness of the mentoring process, which begins by matching the mentor and the mentee. Experience and information transfer between the mentor and mentee occur through communication and interaction in this process (Buell, 2004). Thus, mentees gain experience and responsibility. The gap between the mentor and the mentee balances and the mentee completes the process as an individual more qualified than the mentor (Levinson, 1979). Individuals need mentors in various stages throughout their lives. Similarly, in order for the organizations to enhance their capacities and achieve professional progress, the mentor-mentee relationships in the mentoring process should be at desired levels.

Mentorship practices began to be discussed in the academic agenda after the articles by Kathy E. Kram were published in 1980 and 1983, together with positive outcomes mentorship was observed to be implemented in various fields such as health and business administration (Karakose, Yirci, Uygun \& Ozdemir, 2016). The partners of the mentoring process can be administrators and workers; in educational institutions they can be students and teachers or inspectors and teachers (Rosser, 2005). In America and many European countries, mentoring programs are concentrated on teacher training programs in the field of education (Barrera, Braley \& Slate, 2010). At this point, it is evident that as a mentor, the advisor is a source of information and a guide, shares his experience and knowledge and strives to improve the student's personal performance (Ozkalp, Kirel, Sungur \& Cengiz, 2006).

In order to survive in this rapidly changing, developing and globalizing world; one must effectively benefit from scientific and technological innovations and adapt these innovations to his or her life. It is not difficult to guess the difficulties that a teacher can encounter throughout the first years of his or her profession. Each aid that is offered to them in overcoming these difficulties will not only increase the quality of educational systems but will also play a key role in benefitting from individuals that are trained. Mentorship is a powerful aid bestowed to young and inexperienced teachers (Ozdemir, 2012). Because it aids novice teachers with the strength they need for coping with difficulties, mentorship has become one of the most effective methods in teacher training programs (Griffin, Winn, Otis-Wilbom \& Kilgore, 2003). By increasing the assistance given to teachers through mentorship, teachers who recently began their career became less exhausted and their satisfaction and confidence increased (Whitaker, 2000).

In education, mentor can be defined as an experienced teacher assigned for a novice teacher. Mentoring relationships offer support and feedback to candidate experts and novice teachers and prepare them for the "actual world" in the school and classroom setting (Wood, 2007). Teachers dwell with evaluations demands, curriculum changes, course planning and interact with partners such as parents, students, society and school administrators. Trainee teachers usually complete a set of training practices before getting qualified. During this period, they are forced to work alone for the first time in their lives, without their teachers and class mates, and they are desperately in need of support and feedback to achieve their professional qualification (McLaughlin \& Oberman, 1996). With this respect, displaying mentorship behaviors successfully and creating a sound mentoring relationship will contribute to the student both 
academically and also psycho-socially (Yirci, Karakose, Uygun \& Ozdemir, 2016). This will enable teachers to adapt to their profession and the academic environment and promote job and life satisfaction (Tenenbaum, Crosby \& Gliner, 2001).

In turkey, 40.000 teachers get appointed annually and the number of teachers on duty in the 2015-2016 academic period was 993.794 (National Education Statistics, 2016). After graduating from university, educators must adapt to their educational profession and also to furnishing their students with desired values and behaviors, they also need to dwell with official operations. In their early years, teachers are observed to have difficulties in selecting instructional methods and techniques (Kettle \& Sellars, 1996), classroom management and tolerating with undesired student behaviors (Haggarty, 1995). Thus, it is crucial to train teachers more competently and to promote their professional development while on duty. Mentorship is an effective method for on-the-job training and professional development (Kocabas \& Yirci, 2011; Kemmis, Heikkinen, Fransson, Aspfors \& Edwards-Groves, 2014).

The difficulty in contacting experienced teachers that novice teachers, who are on duty in rural regions, encounter indicates that mentorship is a significant service that should be provided for teachers who have recently been appointed to a job in rural regions. The purpose of this study was to determine whether or not teachers working in rural regions require mentorship practices. Teachers are the principal variable in conducting educational activities at maximum efficiency and convenient with the goals and aims of the educational system. Thus, this study is expected to contribute to the field in emphasizing the importance of supporting the professional development of teachers.

First years of the profession for beginning teachers are very crucial in terms of their further career (Veeman, 1984). Early career teachers in Turkey have to start their teaching profession in rural regions and they face many problems (Sağlamer, 1975). Adaptation problems, problems in evaluating students' performance, managing classroom, motivating students are some of the important problems that early career teachers face (Güçlü, 2004; Korkmaz, Saban ve Akbaşl1, 2004; Sünbül, 2005). As early career teachers need more professional support, it is a must to plan detailed development activities for them (Feiman-Nemser, Carver, Schwille ve Yusko, 1999). From this perspective, the purpose of this study is to identify the problems that early career teachers working in rural regions encounter and to determine their needs for mentorship services. Research questions of this specific research are as the following:

Which problems do the early career teachers face during the first years of the profession?

What mentoring needs do the early career teachers have?

\section{METHOD}

The study was conducted through the content analysis method which is a qualitative research method. Qualitative studies aim at answering to the question "how" rather than "what" (Silverman, 2004). Qualitative research methods are used in order to understand how the participants think about a specific issue in real life (Yin, 2010). Because it offers a deep study on qualitative data, the participants were selected through the purposeful sampling method. The basic criteria while defining study sample was that the teachers should be in their early career phase. In other words, only the teachers who have less than ten years of experience were included into the study sample. The most important factor in qualitative studies is to select participants who will give the most satisfying answers to the interview questions (Maxwell, 2005). A literature review was conducted according to the goals of the study and an interview form consisting of four questions was developed by the researchers. Opinions of field experts $(n=4)$ were collected to check the face validity of the interview form. At this point, in order to revise the interview form appropriate with the study, necessary corrections were made based on the field experts' suggestions and the form gained its final form. In qualitative studies, it is crucial to treat each participant in an equal manner and to collect as much data as possible so as to enable reliability (Denzin \& Lincoln, 2000). The questions in the interview form are as the following:

Did you have difficulties in the implementation of the educational program or in the effectiveness of executing the lessons? Please explain with examples.

Did you have any problems in presenting the teaching contents and conveying the subject? Please explain with examples. 
Can you explain the problems you encountered concerning student behaviors in and out of the classroom setting during the early years of the profession?

Did you have any administrative problems with the school administration or the Provincial/District Directorate for National Education?

The researchers distributed the interview forms to the teachers and the forms were collected a week later in order to ensure that the teachers could give detailed written answers to the questions. All the completed forms were examined by each of the researchers and then the data was transferred into MS Word processor.

\section{Study Group}

The study group consisted of 11 classroom teachers working in rural regions during 2015-2016 academic year. All the participants were selected randomly from the rural areas and they participated into the research on the voluntary basis. The researchers gave brief information regarding the purpose and procedure of the research and the interview forms were collected anonymously. Some demographic features of the participants can be seen on table 1 .

Table 1. Demographic characteristics of the participants

\begin{tabular}{llll}
\hline Participants & Gender & Age & Seniority \\
\hline 1 & Female & 27 & 4 \\
2 & Male & 26 & 2 \\
3 & Male & 25 & 1,5 \\
4 & Male & 31 & 8 \\
5 & Male & 25 & 2 \\
6 & Male & 26 & 3 \\
7 & Female & 26 & 3 \\
8 & Male & 27 & 3 \\
9 & Male & 25 & 2 \\
10 & Female & 25 & 2 \\
11 & Male & 29 & 5,5 \\
\hline
\end{tabular}

As it can be seen on the table participants' ages range between 25 and 31. The arithmetic mean of the seniority of the teachers is approximately 3 years. It means that the teachers in the study group can be defined as novice teachers. The study group consists of 3 female and 8 male teachers.

\section{Data Analysis}

The interview forms collected from the participants were coded as “G1, G2, G3, ..., G11” and transcribed to the computer. The data were analyzed based on the content analysis method. Similar statements were classified into groups. Because participant opinions reflected more than one theme, the number of opinions placed under the themes was more than the total number of opinions. In order to identify whether participant opinions were in accordance with the category they were placed under, expert opinions were collected. With this respect, the experts were asked to place each participant opinion under the categories determined by the researchers. 4 opinions out of the 55 opinions stated by the participants were placed under different categories by the experts. In order to promote reliability of the data collected through the content analysis, the "Consensus Percentage $(\mathrm{P})=$ Consensus / (Consensus + Dissent) x 100" formula developed by Miles and Huberman (1994) was used. The reliability ratio among the researchers was calculated as $\mathrm{P}=51 /(51+4) \mathrm{X} 100=\sim 93 \%$. For the reliability of qualitative studies, the consensus percentage should be 70\% (Miles and Huberman, 1994) and above. These findings indicate that the study has a sufficient level of reliability.

\section{FINDINGS and INTERPRETATIONS}

The participants were initially asked whether or not they had difficulties in the implementation of the educational program or in the effectiveness of executing the lessons. According to the data analysis conducted on 11 participants; all of the participants stated that they had a problem in effectively using the time. When participant opinions are considered, this is due to the lack of professional experience. The participants expressed that when they performed the activities in the program, they had no time left 
for the learning contents, that they couldn't fully consider the differences between the students' academic achievement levels and that their work load was more than they expected. They stated that because they were in a rural region, the socio-economic conditions of the majority of the families were at a low level and this led to a decline in effective family participation. The fact that students studying in schools within rural regions don't have enough space for social activities has been regarded as a serious problem for program outputs. Outstanding participant opinions on this issue are given below: G2: It is impossible to implement the programs within the particular time. The difference in the levels of readiness and intelligence between students causes a decrease in the effectiveness of lessons and prevents the subjects to be comprehended. A one-to-one education and a different curriculum is necessary for inclusive students in the classroom but there is no time for this. I have two inclusive students in my classroom and I always get them to draw pictures because I don't have the opportunity to deal with them. I usually spend my afternoon break with administrative operations.

The participants were asked the question, "Did you have any problems in presenting the teaching contents and conveying the subject?" and their responses were analyzed. The themes where participant opinions were placed under are given in Figure 1:

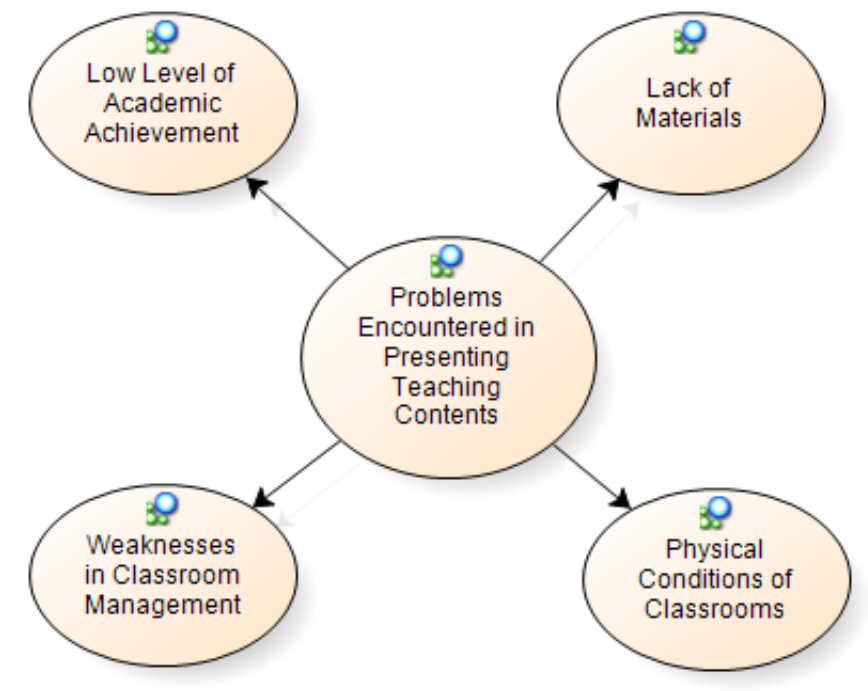

Figure 1. Problems encountered in presenting teaching contents.

Seven participants underlined that families living in rural regions have rather low socio-economic conditions and that the academic achievement levels of students are low because they receive very low support from their families. They stated that low educational status of the families and the opinions of the families about education are determinants of this issue. They expressed that educational outputs are not at sufficient levels because the students' academic achievement levels are low and that they have difficulties in increasing academic achievement. Four participant's opinions indicated that the facilities in schools are not at desired levels, the classrooms are small, the number of students are too much and that they encountered difficulties in classroom management due to the negative conditions of classrooms $(n=5) .10$ different statements of nine participants suggested that they had difficulties in presenting teaching contents due to the lack or insufficient amount of teaching materials within the schools they work in. Participants stated they lack of materials is a serious problem in applied courses and in concretizing abstract subjects. Some of the participant opinions stated about the problems encountered while presenting teaching contents are given below:

G5: Outcomes of the things learnt in theory can be different in practice. I realized that the courses I took in university were very different from the actual classroom setting once I started working in my school. When the explained and presented subjects don't appeal to students then learning doesn't take place. I couldn't access the electronic materials because our computer and the internet connection was frequently out of order. For example, because we didn't have a skeleton in our school, we had difficulty teaching our body in the Biology course. 
G7: My school is very old and the size of the classrooms is too small. Families in the region where the school is being usually crowded and this affects the classrooms as well. We carry out lessons with 3035 students in classrooms arranged for 18-20 students. Because my classroom is too crowded I have difficulty in classroom management and encounter problems in accomplishing the goals of the curriculum. This decreases the effectiveness of learning.

The participants were asked to explain the problems they encounter concerning student behaviors in and out of the classroom setting and their problems were categorized under three titles. Three participants stated that educational status of the families were either too low or insufficient due to the social environments of the schools they worked in. They expressed that they couldn't get enough support from families to achieve the teaching goals and that family participation was too low. Participants, who emphasized the role of family participation in overcoming undesired student behaviors, stated that families with low educational status failed to help teachers on this issue. With five different opinions, the participants stated that they encountered problems resulting from the physical deficiencies, for example lack of lighting, small classrooms and crowded classrooms. Participant opinions on this issue were placed under the Educational Status of Families theme. Four participants stated that they encountered problems "resulting from the "physical conditions of the classrooms" due to small and too crowded classrooms. The majority $(\mathrm{n}=12)$ of the opinions concerning problematic student behaviors were placed under the student tendencies for violence theme. Outstanding participant opinions on the related study question are given below:

G3: Students commit violence on each other while in the classroom and out of the school. What is strange is that they see this violence as a game. When I contact the parents to find a solution they say that it is quite normal. Families just laugh at the swear words and insults.

G6: One day during recess I saw that the students were grouped into two and were hitting each other with thick rods. I thought that the school was separated into two and was fighting. I found out that this was a local game. If it wasn't a game, as a woman, I wasn't going to be able to do anything. Later on I called my friend and asked what I should do if I had faced such an issue.

The teachers in the study group were asked whether or not they experienced any administrative problems with the school administration or the Provincial/District Directorate for National Education during the first two or early years of their profession. All of the participants expressed that they had problems with the school administration and the provincial/District Directorate for National Education on administrative issues. In general, the participants stated that they didn't receive much information about the procedure related to administrative issues during their undergraduate education, that because they were newly appointed they were inexperienced in these issues and that they couldn't effectively use their time neither for education nor the administrative issues. Participants, who emphasized that administrative operation should be fully carried out so as for them to carry out their duties effectively, stated that in order to conduct administrative operations successfully, the physical means (computer, printer, internet connection etc.) of the school should not cause troubles. Participants underlined that in order to prevent such troubles, necessary regulations should be made in undergraduate curriculums and teachers should receive in-service training or attend to seminars on how to carry out administrative operations. Two participants' opinions are given below:

G6: Like every teacher, I went through these difficulties as well. The reason is because none of the appointed teachers took a course in university on how to manage administrative issues. If they have an acquaintance they seek their help in managing administrative operations. I had a friend who was appointed before and got his assistance about many issues. He explained me in detail especially the rules for writing official documents.

G10: Yes, very much. Seeing that I can manage both the administrative issue and teaching, I gave up on the administrative ones. Although the District Directorate for National Education took a statement down on me I still (couldn't) do them. There was no body that I could seek help from. The inspectors who came for audit mentioned about administrative operations but ignored the importance of enhancing the school's physical condition and student achievement.

In this study, problems that the teachers encountered about the educational program, about presenting the teaching content, about student behaviors and about the administrative operations during their early years in their profession were identified. At this point, by considering the problems that the participants encountered, their request for a supervisor/mentor that can continuously assist them was examined. According to the analyses of participant opinions, all of the participants stated that having a 
supervisor/mentor while encountering problems will comfort them psychologically. They added that by easily and rapidly solving insoluble problems will increase job satisfaction and organizational commitment levels of teachers; by saving the time spared for solving problems will increase the quality of teaching; the ambition of the early years will be sustained and their professional self-confidence will be increased. Solving problems with the assistance of a supervisor/mentor will prevent wasting time due to the lack of knowledge and experience. Some participant statements on this issue are given below: G4: After undertaking such a responsibility for the first time, I didn't know what to do. If I had an assistance, then I wouldn't have had a waste of time and effort. We need to take a seminar about the possible difficulties at least a few weeks before we start our job. In addition, we also need a guide that we can continuously ask questions so as to solve our professional and administrative problems.

G7: I see myself lucky. I had an experienced colleague who would help out. Every newly appointed teacher has to have a supervisor (guide) or they will become reluctant the first minute they begin their profession.

\section{DISCUSSION and CONCLUSION}

The aim of this study was, with the participation of 11 teachers, to determine whether or not teachers who work in the rural regions require mentoring services during the early years of their professions. Teachers working in rural regions were observed to have difficulties especially in time management during their early years. This is considered as a problem related to excessive workload for teachers who lack professional experience. It is important for an advisor or a mentor to guide inexperienced teachers so that they can overcome this period by showing fewer weaknesses. Teachers are responsible for operating their bureaucratic duties as well as implementing and managing educational activities. Because they have excessive and a wide range of work load, it is probable that they cannot complete their duties on time.

One other result of the study is that teachers working in rural regions have difficulties in effectively and sufficiently presenting the learning contents during the early years of their profession. It is an inevitable fact that students have different academic achievement levels within the classroom, which can be defined as a living setting. At this point, it is crucial that teachers completely contribute to the learning experiences of all students. It will be rather difficult for teachers, who are inexperienced during their early years, to accomplish this without receiving any support. It is actually normal for teachers to undergo problems on this issue. This finding is in line with findings of other (McLaughlin \& Oberman, 1996) studies. Teacher statements expressing that they have difficulties in classroom management can be considered the same way. Teacher opinions expressing that material requirements in rural schools are not fully met and that physical conditions such as lighting and heating are not at desired levels constitute a serious problem for the Turkish educational system.

The mentoring process not only teaches how to be an effective teacher but also teaches how to make daily planning (Clark \& Byrnes, 2012). Teachers underlined that they encounter problems concerning classroom management because families don't or cannot offer the support in tolerating against undesired student behaviors. Family participation is crucial in the effectiveness of teaching (Krupp, 1985; Little, Gallagher \& O’Neal, 1984]. Otherwise the extent of practicing educational goals will decrease and the productivity in education will be negatively affected. The professional development of teachers should be supported by experienced teachers so as to prevent such problems from occurring (Daresh \& Playko, 1992). One other fact is that students have the tendency for violence and that teachers have difficulties in overcoming this problem. Recently, violence among students has increased. Students who resort to violence against the problems they encounter or in solving the issues among each other, harm themselves, their peers, their teachers and close surroundings. Violence during childhood and adolescence has become one of the serious problems of our era (Demir \& Kumcagiz, 2015). It is crucial that teachers, who lack the experience in resolving the problem, should be under the guidance of a mentor.

Having difficulties in administrative issues during the early years of the profession can be expectable. Updating the curriculums of undergraduate programs can be a solution for solving this problem. Teachers, who are on duty and who work in rural regions where they cannot easily seek help from their colleagues, should be given the opportunity to participate in on-the-job training activities. The mentoring process not only teaches how to be an effective teacher but also teaches how to make daily planning 
(Clark \& Byrnes, 2012) and thus, offering mentorship services to inexperienced teachers is vital. In addition, the participants also stated that they need an advisor/mentor in resolving the problems they encounter. As (Crow \& Matthew, 1998) emphasizes, beginning mentoring programs for educational leadership has been frequently suggested in many studies. In achieving this goal, problems can be resolved more effectively and rapidly under the assistance of more experienced mentors and as a result deviating from organizational goals will be prevented. Thus, job satisfaction levels of teachers can be positively affected through effectiveness of schools.

\section{REFERENCES}

Barrera, A., Braley, R. T. \& Slate, J. R. (2010). Beginning teacher success: an investigation into the feedback from mentors of formal mentoring programs. Mentoring \& Tutoring: Partnership in Learning. 18(1), 61-74.

Bozionelos, N. (2004). Mentoring provided: Relation to mentor's career success, personality, and mentoring received. Journal of Vocational Behavior, 64(1), 24-46.

Brescia W. F. (2002). Using a Telementoring Taxonomy in a World Wide Web Instructional Environment: A Case Study. Unpublished doctoral dissertation, Indiana University, Bloomington.

Buell, C. (2004). Models of mentoring in communication. Communication Education, 53(1), 56- 73.

Cakir, L. \& Kocabas, I. (2016). Mentoring in Gifted Student's Education and a Model Suggestion. Educational Process: International Journal, 5(1), 76-90.

Clark, S.K. \& Byrnes, D. (2012). Through the eyes of the novice teacher: perceptions of mentoring support. Teacher Development: An international journal of teachers' Professional development, 16(1), 43-54. doi: 10.1080/13664530.2012.666935

Clutterbuck, D. \& Ragins, B. R. (2002). Mentoring and Diversity. Oxford: Butterworth-Heinemann.

Crow, G. \& Matthews, L. J. (1998). Finding one's way: How mentoring can lead to dynamic leadership. Thousand Oaks, CA: Corwin Press.

Daresh, J. \& Playko, M. (1992). Perceived benefits of a preservice administrative mentoring program. Journal of Personnel Evaluation in Education, 1, 15-22.

Demir, Y. \& Kumcagız, H. (2015). Öğrencilerin Anne Baba Tutumlarını Algılama Biçimleri ve Şiddete Eğilimleri, Turkish Studies-International Periodical for the Languages, Literature and History of Turkish or Turkic, 10 (2), 221-23. ISSN: 1308-2140. DOI Number: 10.7827/TurkishStudies.7696

Denzin, N. K. \& Lincoln, Y. S. (2000). Handbook of qualitative research. London: Sage Publications.

Feiman-Nemser, S., Carver, C., Schwille, S., \& Yusko, B. (1999). Beyond support: Taking new teachers seriously as learners. In M. Scherer (Ed.), A better beginning: Support and mentoring new teachers (pp. 3-12), Virginia: ASCD.

Griffin, C. C., Winn, J. A., Otis-Wilborn, A. \& Kilgore, K. L. (2003). New teacher induction in special education (The Center on Personnel Studies in Special Education). http://www.copsse.org. Accessed on 22.09.2016.

Godshalk, V. M., \& Sosik, J. J. (2003). Aiming for career success: The role of learning goal orientation in mentoring relationships. Journal of Vocational Behavior, 63(3), 417-437.

Güçlü, N. (2004). Öğretmenlik mesleğine başlarken yeni ögretmenlerin örgütsel sosyalleşmeleri (1. Basım). S.Ş.Erçetin. (Ed.), İlk günden başöğretmenliğe (ss.15-36). Ankara: Asil Yayıncılık.

Haggarty, L. (1995). The use of content analysis to explore conversations between school teacher mentors and student teachers. British Educational Research Journal, 21, 183- 197.

Harris, R.M. (1993). The mentoring trap. Library Journal, 118 (17), 37-39.

Karakose, T., Yirci, R., Uygun, H., Ozdemir, T.Y. (2016). Post-Graduate Students' Perceptions Regarding Effectiveness of Mentoring Relationship at Universities. Revista de Cercetare si Interventie Sociala, 52, 252-264.

Kemmis S, Heikkinen HLT, Fransson G, Aspfors J, Edwards-Groves, C. (2014). Mentoring of new teachers as a contested practice: Supervision, support and collaborative self-development. Teaching and Teacher Education, 43, 154-164.

Kettle, B. \& Sellars, N. (1996). The development of student teachers' practical theory of teaching. Teaching \& Teacher Education, 12, 1- 24.

Klasen, N. \& Clutterbuck, D. (2002) Implementing Mentoring Schemes. Oxford: Butterworth Heinemann Publishing.

Klasen, N. \& Clutterbuck, D. (2005). Implementing Mentoring Schemes, A Practical Guide to Successful Programs, Butterworth-Heinemann, USA.

Kocabas, I. \& Yirci, R. (2011). Öğretmen ve Yönetici Yetiștirmede Mentorluk Mentorluğun Ë̆itimde Kullanılması, Ankara: Ani Yayincilik.

Korkmaz, İ., Saban, A., Akbaşlı, S. (2004). Göreve yeni başlayan sınıf öğretmenlerinin karşılaştıkları güçlükler. Kuram ve Uygulamada Eğitim Yönetimi, 38, 266-277 
Krupp, J. (1985). Mentor and protégé perceptions of mentoring relationships in an elementary school in Connecticut. Paper presented at the annual meeting of the American Educational Research Association, New Orleans, LA.

Levinson, D. J. (1979). The seasons of a man's life. New York, NY: Alfred A. Knopf.

Little, J. W., Gallagher, P. \& O’Neal, P. (1984). Professional development roles and relationships: Principles and skills of "advising” (Contract No. 400-83-003). San Francisco: National Institute of Education.

Maxwell, J. A. (2005). Qualitative research design: An interactive approach (2nd ed.). Thousand Oaks, CA: Sage.

McLaughlin \& I. Oberman (Eds), Teacher learning: New policies, new practices (ss. 92-114). New York, NY: Teachers' College Press.

McManus, S. E., \& Russell, J. E. A. (1997). New directions for mentoring research: An examination of related constructs. Journal of Vocational Behavior, 51(1), 145-161.

National Education Statistics, Formal Education 2015/'16, Ankara: Ministry of National Education, http://sgb.meb.gov.tr/meb_iys_dosyalar/2016_03/18024009_meb_istatistikleri_orgun_egitim_2015_2016 .pdf Accessed on 01.08.2016.

Ozdemir, T. Y. (2012). E-mentoring model for maintaining the provincial education inspectors and assistant inspectors' professional development, Unpublished Doctorate Dissertation, Firat University, Elazig, Turkey.

Ozkalp, E., Kirel, C., Sungur, Z. \& Cengiz, A. A. (2006). The Importance of Mentoring on Organizational Socialization of the Research Assistants in Anadolu University. Anadolu University Journal of Social Sciences, 6(2), 55-70.

Roberts, A. (2000). Mentoring revisited: A phenomenological reading of the literature. Mentoring and Tutoring, 8(2), 145-170.

Rosser, H. M. (2005). Mentoring from the Top: CEO Perspectives. Advances in Developing Human Resources, 7 (4), 527-539.

Sağlamer, E. (1975). Eğitimde teftiş teknikleri. Ankara: Milli Eğitim Basımevi.

Silverman, D. (2004). Interpreting qualitative data: A guide to the principles of qualitative research (4th ed.). Thousand Oaks, CA: Sage.

Singh, V., Bains, D., \& Vinnicombe, S. (2002). Informal mentoring as an organizational resource. Long Range Planning, 35(4), 389-405.

Sosik, J. J. \& Lee, D. (2005). Context and Mentoring: Examining Formal and Informal Relationships in High Tech Firms and K-12 Schools. Journal of Leadership and Organizational Studies, 12 (2), 94-108.

Sünbül, A. M. (2005). Bir meslek olarak ögretmenlik (2. Basım). Ö.Demirel ve Z.Kaya (Eds), Öğretmenlik mesleğine giriş (ss. 245-278). Ankara. Pegem A Yayıncılık.

Strong, M. (2009). Effective teacher induction and mentoring: Assessing the evidence. New York: Teachers College Press.

Tenenbaum, H. R., Crosby, F. J. \& Gliner, M. D. (2001). Mentoring relationships in graduate school. Journal of Vocational Behavior, 59(3), 326-341.

Underhill, C. M. (2006). The effectiveness of mentoring programs in corporate settings: A meta-analytical review of the literature. Journal of Vocational Behavior, 68, 292-307.

Veenman, S. (1984). Perceived problems of beginning teachers. Review of Educational Research, 54(2), 143-178.

Whitaker, S. D. (2000). Mentoring beginning special education teachers and the relationship to attrition. Exceptional Children, 66, 546-566.

Wood, E. D. (2007). E-mentoring as a means to develop and retain expatriate managers. International Research Conference in the Americas of the Academy of Human Resource Development (Indianapolis, IN, Feb 28Mar 4, 2007).

Yin, R. K. (2010). Qualitative research from start to finish. New York: Guilford Press.

Yirci, R. \& Kocabas, I. (2010). The importance of mentoring for school principals: A conceptual analysis. International Journal of Educational Leadership Preparation, 5(2), 1-7.

Yirci, R., Karakose, T., Uygun, H. \& Ozdemir, T. Y. (2016). Turkish Adaptation of the Mentorship Effectiveness Scale: A validity and Reliability Study. Eurasia Journal of Mathematics, Science \& Technology Education, 12(4), 821-832.

Young, A. M., \& Perrewe, P. L. (2000). What did you expect? An examination of career-related support and social support among mentors and protégés. Journal of Management, 26(4), 611-632. 


\section{TÜRKÇE GENIŞLETILMIŞ ÖZET}

Kavram olarak Yunan mitolojisindeki Odyssey Destanı'na (Harris, 1993; Strong, 2009) kadar uzanan mentor, günümüzde acemi bireylerin uzman kişiler tarafından mesleki açıdan geliştirilmesini destekleyen kişi olarak adlandırılmaktadır (Roberts, 2000; Cakir \& Kocabas, 2016). Mentora gelişiminin desteklenmesi için teslim edilen ve daha az deneyime sahip kişi mentee (Klasen \& Cluutterbuck, 2002) ve mentor ile mentee arasında bilgi ve deneyim paylaşımının gerçekleştiği süreç ise mentorluk süreci olarak tanımlanır (Ozdemir, 2012). Mentorluk, eşit statüde olmayan ya da düşük statüde olan kişilerin organize olmasını içeren bir ilişki ya da usta (çok tecrübeli) ve çırak (az tecrübeli) arasındaki uzun dönemli yoğun bir ilişki şeklidir (Godshalk and Sosik, 2003; Kocabas \& Yirci, 2011; McManus \& Russell, 1997; Singh, Bains, \& Vinnicombe, 2002; Young \& Perrewe, 2000; Bozionelos, 2004).

Kathy E. Kram'ın 1980 ve 1983 yıllarında yayınladığg iki makale ile akademik alanda tartışılmaya başlanan mentorluk uygulamalarından elde edilen olumlu sonuçlarla birlikte mentorlüğün sağlık sektöründen, işletme yönetimine kadar birçok farklı alanda uygulandığı görülmektedir (Karakose, Yirci, Uygun \& Ozdemir, 2016). Mentorluk sürecinin paydaşları yöneticiler, işgörenler ya da eğitim örgütlerindeki öğrenci ile öğretmenler, eğitim denetmenleri ile öğretmenler olabilir (Rosser, 2005). Özellikle Amerika ve Avrupa ülkelerinde eğitim alanında öğretmen yetiştirme üzerine yoğunlaşan mentorluk programları görülmektedir (Barrera, Braley \& Slate, 2010). Bu aşamada, danışman hocanın mentor olarak bir bilgi kaynağ 1 ve yönlendirici olduğu, tecrübesini ve bilgisini paylaştığ 1 , öğrencinin kişisel performansını arttırmaya yönelik çaba harcadığı bilinmektedir (Ozkalp, Kirel, Sungur \& Cengiz, 2006).

Hızla değişen, gelişen ve küreselleşen dünyamızda hayatta kalmayı sürdürebilmek; ancak bilim ve teknolojinin getirdikleri yenilikleri verimli biçimde kullanarak ve bu yenilikleri hayata adapte ederek gerçekleşebilir. Mesleğinin ilk yıllarında bir öğretmenin karşılaşabileceği zorlukları hayal etmek zor değildir. Bu zorlukların üstesinden gelmesinde ona uzatılan her el, hem eğitim sistemlerinin kalitesini artıracak, hem de yetiştirilmesi hedeflenen bireylerin hayata kazandırılmasında önemli bir rol oynayacaktır. Mentorluk bu yolda genç ve tecrübesiz öğretmenlere uzatılan güçlü bir eldir (Ozdemir, 2012).

Göreve yeni başlayan öğretmenlere karşılaşacakları zorluklarla mücadele gücü vermesinden dolayı mentorluk öğretmen yetiştirme programlarının en etkili yöntemlerinden biri olmuştur (Griffin, Winn, Otis-Wilbom \& Kilgore, 2003). Öğretmenlere mentorluk aracılığıyla sağlanan bu yardımın artmasıyla, mentorluk yeni kariyer yapan öğretmenlerin yıpranmasını azaltıp onlara memnuniyet ve güven kazandırmıştır (Whitaker, 2000).

Türkiye'de yıllık ortalama 40.000 kadar yeni öğretmen göreve başlamaktadır. 2015-2016 eğitim öğretim y1lı itibariyle görevli öğretmen sayısının 993.794 olduğu görülmektedir (National Education Statistics, 2016). Lisans düzeyinde alınan eğitim sonrası eğitimciler bir yandan eğitim-öğretim işlerine diğer yandan öğrencilere istendik değerler ve davranışlar kazandırmaya adapte olmaları gerekmekte, aynı zamanda resmi işlerle uğraşmak zorunda kalmaktadırlar. Özellikle görevlerinin ilk yıllarında öğretmenler, öğretim yöntem tekniklerinin seçimi (Kettle \& Sellars, 1996), sınıf yönetimi ve istenmeyen öğrenci davranışlarının tolere edilmesinde zorluk yaşadıkları bilinmektedir (Haggarty, 1995). Bu noktada öğretmenlerin yetiştirilirken daha donanımlı bir şekilde yetiştirilmeleri ve mesleki gelişimlerini işbaşında sürdürmeleri önem kazanmaktadır. İşbaşında yetiştirme ve mesleki gelişimin sürdürülmesinde etkili yöntemlerden biri de mentorluktur (Kocabas \& Yirci, 2011; Kemmis, Heikkinen, Fransson, Aspfors \& Edwards-Groves, 2014).

Göreve yeni başlayan ve özellikle kırsalda göreve başlamış olan öğretmenlerin kendilerine rehberlik edecek deneyimli öğretmenlere ulaşmalarının zorluğu, kırsalda göreve başlamış ve görevlerine kırsalda devam eden öğretmenlere sunulması gereken mentorluk hizmetini daha da önemli hale getirmektedir. $\mathrm{Bu}$ araştırmada kırsalda görev yapan öğretmenlerin mentorluk uygulamalarına gereksinimlerinin olup olmadığı belirlenmeye çalışılmıştır. Eğitim-öğretim ekinliklerinin, eğitim sistemi hedef ve amaçlarına uygun ve maksimum verimlilikte gerçekleştirilmesinde başat değişken öğretmendir. $\mathrm{Bu}$ nedenle öğretmenlerin mesleki gelişimlerinin desteklenmesinin gerekçelendirilmesi açısından bu çalışmanın alana önemli bir katkı sağlayacağı düşünülmektedir.

Araştırma nitel araştırma yöntemlerinden içerik analizi yöntemi kullanılarak gerçekleştirilmiştir. Nitel veriler üzerinde derinlemesine çalışma imkanı sağladığından, katılımcılar amaçlı örnekleme yöntemiyle 
belirlenmiştir. Araştırma amaçları doğrultusunda literatür taraması yapılarak, araştırmacılar tarafından dört adet açı uçlu sorudan oluşan görüşme formu hazırlanmıştır. Görüşme formunun görünüş geçerliliğini sağlamak amacıyla alan uzmanlarının $(n=4)$ görüşlerine başvurulmuştur. Bu aşamada alan uzmanlarından hazırlanan görüşme formunun, araştırma amacına uygun hale getirilmesi için ileri sürdükleri düzeltmeler yapılarak, görüşme formuna son şekli verilmiştir. Araştırmanın çalışma grubu 2015-2016 öğretim yılında kırsalda görevli 11 sınıf öğretmeni oluşturmaktadır. Katılımcılardan alınan görüşme formları "G1, G2, G3, .., G11" şeklinde kodlanarak bilgisayar ortamına aktarılmıştır. İçerik analizi süreçleri yürütülerek veriler çözümlenmiştir.

Araştırma bulgularına gore görevinin ilk yıllarında kırsalda görevli öğretmenlerin özellikle zaman yönetiminde sıkıntı yaşadıkları belirlenmiştir. Bu durum, mesleki deneyim açısından yetersiz olan öğretmenlerin yoğun iş yükü arasında yaşanılabilecek bir sorun olarak karşımıza çıkmaktadır. Yalnız bu sürecin daha az zaafiyetle atlatılması açısından deneyimi az öğretmenlere yol gösterici ya da bir mentorun rehberlik etmesi önemlidir. Araştırma ulaşılan sonuçlardan bir diğeri ise kırsalda görevli öğretmenlerin görevlerinin ilk yıllarında öğretim içeriklerinin etkili ve yeterli bir şekilde sunumunda da sorunlar yaşıyor olmalarıdır. Bu durumun sebebi olarak kırsal bölgelerdeki okullarda materyal gereksinimlerinin yeterli düzeyde karşılanmaması ve sınıfların aydınlatma, ısınma gibi fiziki şartlarının istenen düzeyde olmaması gösterilmiştir. Araştırma bulguları kapsamında istenmeyen öğrenci davranışlarıyla başedilmesinde öğretmenlerin ailelerden yeterli desteği sağlayamadıkları ortaya çıkmaktadır. Buna bağlı olarak sınıf yönetiminde zaafiyetlerin yaşandığg belirlenmiştir. Bu olumsuz durumların yaşanmaması açısından öğretmenlerin deneyimli öğretmenlerin rehberliği altında mesleki gelişimlerine katkı sağlanması önemlidir (Daresh ve Playko, 1992). Araştırma kapsamında görevlerinin ilk yıllarında öğretmenlerin idari işlerin yürütülmesinde de sorunlar yaşadıkları tespit edilmiştir. $\mathrm{Bu}$ durumun giderilmesi açısından öğretmenlerin lisans eğitimlerinde ders içeriklerinin güncellenmesi faydalı olabilir. Araştırmaya katılan öğretmenler yaşamış oldukları sorunların çözümünde deneyimli bir öğretmenin rehberliğinin önemli olduğunu ve bir danışmana/mentora ihtiyaç duyduklarını belirtmişlerdir.

Araştırma bulgularından elde edilen sonuçlar ışığında deneyimsiz öğretmenler için daha nitelikli, planlı ve programlı mentorluk programlarının başlatılması bir çözüm yolu olarak düşünlebilir. Bunun gerçekleşmesi durumunda daha deneyimli mentorlar eşliliğinde karşılaşılan sorunlar daha etkili ve hızlı bir çözüme kavuşturulabileceğinden örgütsel amaçlardan uzaklaşmalar da olmayacaktır. Bu sayede okullarının etkililiği ile öğretmenlerin iş doyum düzeylerine pozitif katkı sağlanabilir. 